\title{
Studies on Cerebral Circulation and Metabolism in Hypertensive Diseases
}

III. The Effect of Prolonged Oral Administration of Hypotensive Agents upon the Cerebral Circulation and Metabolism in Patients with Essential Hypertension

By

Mitsuaki Tateyama

(館山光昭)

From the Department of Internal Medicine, Sendai National Hospital, Sendai. Director: Dr. T. Kato, Professor

Emeritus of Tohoku University

(Received for publication, March 30, 1959)

A series of investigations have been reported on the significance of hypotensive agents in restraining aggravation of the hypertension, preventing the progression of the organic vascular changes and minimizing complications. The studies on cerebral circulation and metabolism under lowered blood pressure induced by those agents is a theme of importance, but on this subject mainly the acute effect of lowering blood pressure by those agents has been investigated, and reports on the effect of prolonged oral administration, the mode of application clinically most important, are few.

From this view-point, the author undertook a study on the changes of the cerebral circulation and metabolism following prolonged oral administration of the hypotensive agents in patients with essential hypertension.

As hypotensive agents, Serpasil alone or in combination with Apresoline was used.

\section{EXPERIMENTAL}

\section{Method}

Of the patients with essential hypertension, who were admitted in the wards of Sendai National Hospital and were measured for their cerebral circulation and metabolism by $\mathrm{N}_{2} \mathrm{O}$ method after stabilization of the blood pressure in about a week after their hospitalization, 11 cases with the blood pressure gently lowered in 9-60 days, in 22 days on an average, by continued oral administration of hypotensive agents, were selected, and the cerebral circulation and metabolism were measured for comparison with 
the values before the use of the agents. The subjects thus selected ranged between 43 and 65 years, 54 years in mean age, were free of any complicating cardiac, renal or cerebral vascular disturbances and comprised 4 cases of I grade, 5 cases of II grade and 2 cases of III grade of the retinal findings according to Keith-Wagener's classification, thus consisting in rather mild cases.

These subjects were divided into the group of 7 cases administered with Serpasil alone and the group of 4 cases treated with Serpasil in combination with Apresoline. Method of measurement and units of the values concerning cerebral circulation and metabolism used in the present report are as detailed in the first report ${ }^{11}$.

\section{Results}

1. The effect on the cerebral circulation and metabolism of administration of Serpasil alone

The values concerning the cerebral circulation and metabolism of 7 cases with essential hypertension before and after lowered blood pressure by administration of Serpasil alone are shown in comparison in Table I. The age of these subjects ranged between 43 and 61 , averaging 52 years; 3 of them were in I grade group, 2 in II grade group and 2 in III grade group of retinal findings according to Keith-Wagener's classification. Sepasil was administered daily $0.4-0.8 \mathrm{mg}$., for 9-33 days, for 20 days on an average.

MABP was found lowered in all the cases, by $-23.1 \%$ on an average, while CBF was found risen in 4 (cases 1, 2, 3 and 5), fallen in 2 (cases 4 and 6) but remained unchanged in 1 (case 7), showing a slight increase of $+10.3 \%$ on an average. CVR was found lowered in all the cases, by $-28.7 \%$ on an average. $(\mathrm{A}-\mathrm{V}) \mathrm{O}_{2}$ was augmented in one case (case 6) alone, remaining unchanged or slightly lowered in all the others, so that in mean, no change was found. $\mathrm{CMRO}_{2}$ was elevated in 4 cases (cases 1, 2, 5 and 7), remained unchanged in 2 (cases 3 and 6) and reduced in 1 (case 4 ), thus showing a slight increase of $+9.2 \%$ on an average.

2. The effect on cerebral circulation aud metabolism of administration of Serpasil in combination with Apresoline

Table II shows the changes of values concerning cerebral circulation and metabolism in 4 cases with essential hypertension after blood pressure reduction due to the combined use of Serpasil and Apresoline. The age range of those patients were between 45 and 65 , averaging 58 years; 1 of them was in I grade, 3 in II grade of Keith-Wagener's classification. 0.4$0.8 \mathrm{mg}$. of Serpasil and 60-200 mg. of Apresoline were applied daily for 19-60 days, 32 days in mean.

MABP was reduced in all the cases, by $-18.8 \%$ on an average. 
TABLE I

The Effect of Administration of Serpasil on Cerebral Circulation and Metabolism

\begin{tabular}{|c|c|c|c|c|c|c|c|c|c|c|}
\hline ठूँ & Name & $\stackrel{0}{\alpha}$ & 3 & & MABP & $\mathrm{CBF}$ & CVR & $(A-V) O_{2}$ & $\mathrm{CMRO}_{2}$ & Dosage \\
\hline 1 & M.H. & 51 & I & $\begin{array}{l}\text { B } \\
\text { A }\end{array}$ & $\begin{array}{l}156 \\
130\end{array}$ & $\begin{array}{l}48.6 \\
59.8\end{array}$ & $\begin{array}{l}3.21 \\
2.17\end{array}$ & $\begin{array}{l}6.46 \\
6.30\end{array}$ & $\begin{array}{l}3.14 \\
3.77\end{array}$ & $\begin{array}{l}0.8 \mathrm{mg} \text {. for } 17 \text { days, } \\
0.6 \mathrm{mg} \text {. for another } \\
16 \text { days }\end{array}$ \\
\hline 2 & K.N. & 49 & I & $\begin{array}{l}\text { B } \\
\text { A }\end{array}$ & $\begin{array}{l}150 \\
123\end{array}$ & $\begin{array}{l}40.4 \\
52.0\end{array}$ & $\begin{array}{l}3.71 \\
2.37\end{array}$ & $\begin{array}{l}7.28 \\
6.81\end{array}$ & $\begin{array}{l}2.94 \\
3.54\end{array}$ & $0.7 \mathrm{mg}$. for 9 days \\
\hline 3 & S.T. & 61 & I & $\begin{array}{l}\text { B } \\
\text { A }\end{array}$ & $\begin{array}{l}127 \\
112\end{array}$ & $\begin{array}{l}51.2 \\
60.0\end{array}$ & $\begin{array}{l}2.48 \\
1.87\end{array}$ & $\begin{array}{l}6.73 \\
6.05\end{array}$ & $\begin{array}{l}3.45 \\
3.63\end{array}$ & $\begin{array}{l}0.6 \mathrm{mg} \text {. for } 17 \text { days, } \\
0.8 \mathrm{mg} \text {. for another } \\
5 \text { days }\end{array}$ \\
\hline 4 & K.E. & 43 & II & $\begin{array}{l}\text { B } \\
\text { A }\end{array}$ & $\begin{array}{r}133 \\
90\end{array}$ & $\begin{array}{l}75.2 \\
58.7\end{array}$ & $\begin{array}{l}1.77 \\
1.53\end{array}$ & $\begin{array}{l}5.87 \\
5.83\end{array}$ & $\begin{array}{l}4.41 \\
3.42\end{array}$ & $0.4 \mathrm{mg}$. for 27 days \\
\hline 5 & K.S. & 54 & II & $\begin{array}{l}\mathrm{B} \\
\mathrm{A}\end{array}$ & $\begin{array}{r}113 \\
90\end{array}$ & $\begin{array}{l}56.2 \\
81.6\end{array}$ & $\begin{array}{l}2.00 \\
1.12\end{array}$ & $\begin{array}{l}4.76 \\
4.65\end{array}$ & $\begin{array}{l}2.67 \\
3.79\end{array}$ & $0.4 \mathrm{mg}$. for 15 days \\
\hline 6 & S.W. & 53 & III & $\begin{array}{l}\mathrm{B} \\
\mathrm{A}\end{array}$ & $\begin{array}{l}166 \\
111\end{array}$ & $\begin{array}{l}40.5 \\
32.4\end{array}$ & $\begin{array}{l}4.14 \\
3.41\end{array}$ & $\begin{array}{l}4.41 \\
4.95\end{array}$ & $\begin{array}{l}1.79 \\
1.60\end{array}$ & $0.4 \mathrm{mg}$. for 12 days \\
\hline 7 & K.O. & 56 & III & $\begin{array}{l}\mathrm{B} \\
\mathrm{A}\end{array}$ & $\begin{array}{l}158 \\
112\end{array}$ & $\begin{array}{l}53.5 \\
58.6\end{array}$ & $\begin{array}{l}2.95 \\
1.91\end{array}$ & $\begin{array}{l}4.14 \\
4.63\end{array}$ & $\begin{array}{l}2.21 \\
2.71\end{array}$ & $0.4 \mathrm{mg}$. for 12 days \\
\hline \multicolumn{4}{|c|}{ Mean } & $\begin{array}{l}\mathrm{B} \\
\mathrm{A}\end{array}$ & $\begin{array}{l}143 \\
110\end{array}$ & $\begin{array}{l}52.2 \\
57.6\end{array}$ & $\begin{array}{l}2.89 \\
2.06\end{array}$ & $\begin{array}{l}5.66 \\
5.60\end{array}$ & $\begin{array}{l}2.94 \\
3.21\end{array}$ & \\
\hline \multicolumn{4}{|c|}{ Change } & & $-23.1 \%$ & $+10.3 \%$ & $-28.7 \%$ & $-1.1 \%$ & $+9.2 \%$ & \\
\hline
\end{tabular}

B : Values before administration. A : Values after administration.

K.W. : Keith-Wagener's grade of retinal findings.

CBF increased in all the cases, by $+57.8 \%$ in mean. GVR showed marked fall in all the cases, by $-46.6 \%$ on an average. $(\mathrm{A}-\mathrm{V}) \mathrm{O}_{2}$ remained unchanged in 2 cases (cases 9 and 11), but fallen in 2 (cases 8 and 10), thus by $-14.3 \%$ on an average. $\mathrm{CMRO}_{2}$ was found increased in 2 (cases 8 and 11) but unchanged in 2 (cases 9 and 10), showing an increase of $+29.1 \%$ on an average.

As shown in Table I and II, a more perceptible improvement was seen in cases administered with Serpasil in combination with Apresoline than in the cases given with Serpasil alone. In Fig. 1 are shown the changes in percentage of individual values for cerebral circulation and metabolism following the blood pressure reduction by those agents, together with the retinal findings according to Keith-Wagener's classification. In all cases with Keith-Wagener I, the administration of Serpasil alone or combined with Apresoline, is followed by high percentages in the increase of CBF and $\mathrm{CMRO}_{2}$ and in the decrease of CVR, while the improvement of those values are lessened, as the retinal findings were deteriorated to the II and III grade. In II and III groups of Keith-Wagener there were found even 
TA B L E II

The Effect of Administration of Serpasil in Combination with Apresoline on Cerebral Circulation and Metabolism

\begin{tabular}{|c|c|c|c|c|c|c|c|c|c|c|}
\hline ర్ & Name & 品 & 离 & & MABP & $\mathrm{CBF}$ & CVR & $(\mathrm{A}-\mathrm{V}) \mathrm{O}_{2}$ & $\mathrm{CMRO}_{2}$ & Dosage \\
\hline 8 & S.K. & 59 & $\mathrm{I}$ & $\begin{array}{l}\text { B } \\
\text { A }\end{array}$ & $\begin{array}{l}155 \\
122\end{array}$ & $\begin{array}{l}36.1 \\
73.3\end{array}$ & $\begin{array}{l}4.29 \\
1.66\end{array}$ & $\begin{array}{l}5.37 \\
4.09\end{array}$ & $\begin{array}{l}1.94 \\
3.00\end{array}$ & $\begin{array}{l}\text { Apresoline } 150 \mathrm{mg} \text {. } \\
\text { for } 35 \text { days, Apre- } \\
\text { soline } 150 \mathrm{mg}+ \\
\text { Serpasil } 0.6 \mathrm{mg} \text {. for } \\
25 \text { days }\end{array}$ \\
\hline 9 & K.K. & 45 & II & $\begin{array}{l}\text { B } \\
\text { A }\end{array}$ & $\begin{array}{l}133 \\
107\end{array}$ & $\begin{array}{l}38.2 \\
44.7\end{array}$ & $\begin{array}{l}3.48 \\
2.39\end{array}$ & $\begin{array}{l}5.29 \\
5.41\end{array}$ & $\begin{array}{l}2.02 \\
2.42\end{array}$ & $\begin{array}{l}\text { Serpasil } 0.6 \mathrm{mg} \text {. for } \\
13 \text { days, Serpasil } \\
0.6 \mathrm{mg} \text {. }+ \text { Apresoline } \\
60 \mathrm{mg} \text {. for } 6 \text { days }\end{array}$ \\
\hline 10 & T.A. & 65 & II & $\begin{array}{l}\text { B } \\
\text { A }\end{array}$ & $\begin{array}{l}124 \\
104\end{array}$ & $\begin{array}{l}59.9 \\
95.4\end{array}$ & $\begin{array}{l}2.07 \\
1.10\end{array}$ & $\begin{array}{l}4.60 \\
3.12\end{array}$ & $\begin{array}{l}2.76 \\
2.98\end{array}$ & $\begin{array}{l}\text { Serpasil } 0.6 \mathrm{mg} .+ \\
\text { Apresoline } 100 \mathrm{mg} . \\
\text { for } 12 \text { days, Serpa- } \\
\text { sil } 0.8 \mathrm{mg} .+ \text { Apre- } \\
\text { sline } 200 \mathrm{mg} \text {. for } 30 \\
\text { days. }\end{array}$ \\
\hline 11 & K.A. & 64 & II & $\begin{array}{l}\text { B } \\
\text { A }\end{array}$ & $\begin{array}{r}118 \\
99\end{array}$ & $\begin{array}{l}40.2 \\
61.6\end{array}$ & $\begin{array}{l}2.94 \\
1.61\end{array}$ & $\begin{array}{l}3.43 \\
3.37\end{array}$ & $\begin{array}{l}1.38 \\
2.08\end{array}$ & $\begin{array}{l}\text { Serpasil } 0.8 \mathrm{mg} \text {. for } \\
12 \text { days, Serpasil } \\
0.8 \mathrm{mg} \text {. A Apresoline } \\
100 \mathrm{mg} \text {. for } 7 \text { days }\end{array}$ \\
\hline & Mean & & & $\begin{array}{l}\text { B } \\
\text { A }\end{array}$ & $\begin{array}{l}133 \\
108\end{array}$ & $\begin{array}{l}43.6 \\
68.8\end{array}$ & $\begin{array}{l}3.17 \\
1.69\end{array}$ & $\begin{array}{l}4.67 \\
4.00\end{array}$ & $\begin{array}{l}2.03 \\
2.62\end{array}$ & \\
\hline & Chan & & & & $18.8 \%$ & 70 & -46.6 & $-14.3 \%$ & $+29.1 \%$ & \\
\hline
\end{tabular}

B : Values before administration. A : Values after administration.

K.W. : Keith-Wagener's grade of retinal findings.

cases with lowered CBF and $\mathrm{CMRO}_{2}$, when administered with Serpasil alone.

\section{Case Report}

Further details on one of the cases that showed improvement and one that showed deterioration, following the lowered blood pressure by administration of the hypotensive agents are demonstrated in the following. The case with a marked improvement was a male of 59 years of age, in Keith-Wagener's I grade and was given daily $150 \mathrm{mg}$. of Apresoline for 35 days, then $150 \mathrm{mg}$. of it in combination with $0.6 \mathrm{mg}$. of Serpasil for 25 days. MABP fell by $-21.2 \%$ from 155 to 122, GVR was lowered markedly by $-61.3 \%$ from 4.29 to 1.66 , CBF showed significant increase by $+103 \%$ from 36.1 to 73.3 and $\mathrm{CMRO}_{2}$ also an increase by $+54.6 \%$ from 1.94 to 3.00 - thus an evident improvement being demonstrated.

The case deteriorated after the treatment was a male of 53 years, 

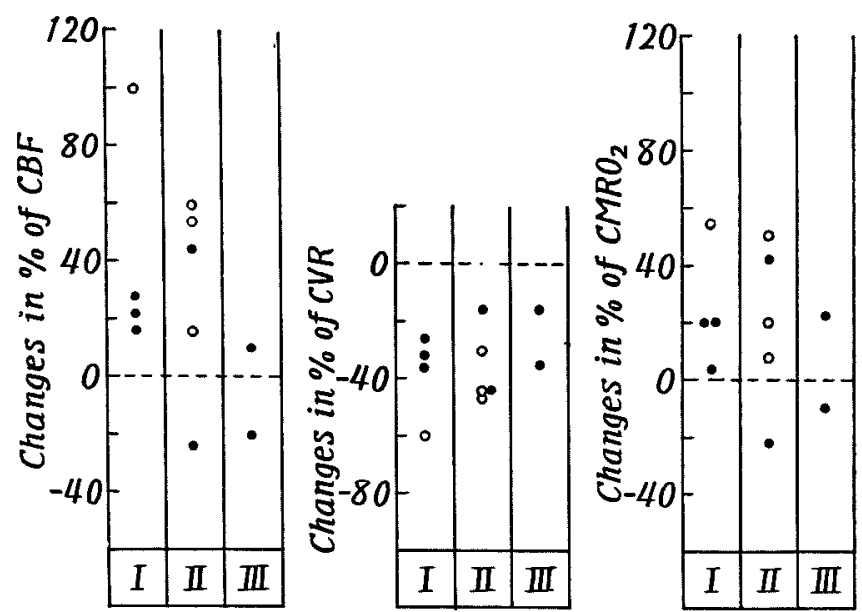

Fig. 1. Relations between retinal findings and changes in individual values for cerebral circulation and metabolism after the administration of hypotensive agents.

- Case administered with Serpasil.

Case administered with Serpasil in combination with Apresoline.

I, II, III : Keith-Wagener's grade of retinal findings.

in Keith-Wagener's III grade. He was given daily $0.4 \mathrm{mg}$. of Serpasil for 12 days. In this case MABP was markedly fallen, by $-33.1 \%$, from 166 to 111 , but CVR fell only slightly by $-17.6 \%$, from 4.14 to 3.41 , $\mathrm{CBF}$ and $\mathrm{CMRO}_{2}$ both decreased, the former by $-20.0 \%$, from 40.5 to 32.4 and the latter by $-10.6 \%$, from 1.79 to 1.60 . The patient soon fell into cerebral softning showing apparent left hemiparesis. This is one of the remarkable cases which showed an apparent aggravation after the hypotensive treatment.

\section{DisGussion}

It is a practically important problem whether or not lowering blood pressure using hypotensive agents acts beneficially upon the cerebral circulation and metabolism in patients with essential hypertension.

The result, of course, may be different according to the grade of the disease, the existance of complications, the kind of hypotensives used, their dosis and mode of administration and besides the degree of lowering the blood pressure. In the cases with essential hypertension without any eminent cardiac, renal or cerebrovascular disturbances selected for the present study, the mild lowering of blood pressure induced by prolonged oral administration of Serpasil alone or in combination with Apresoline resulted in relaxation of cerebrovascular spasm with depression of CVR, and excluding a few exceptinal cases, gave rise to increase in $\mathrm{CBF}$ and 
$\mathrm{CMRO}_{2}$ in the majority of patients and brought about a tendency to return to normal. Considering that the change generally observed in the cerebral hemodynamics in essential hypertension consists in the rise of $\mathrm{CVR}^{213 / 4)}$, further the lowering of $\mathrm{CBF}$ and $\mathrm{CMRO}_{2}$ is often found ${ }^{5 / 6: 11}$ accompanied with advance of the disease, such improvement of the cerebral circulation and metabolism due to the administration of the hypotensives seems likely to exert favourable influence on the function of the brain in the patients with essential hypertension and to be effective in preventing aggravation of the disease and occurence of complications.

Between the results obtained by single administrration of Serpasil and those obtained by combined use of Serpasil and Apresoline, there could be demonstrated some difference. Of course, some difference in the grades of retinal findings was found between both cases investigated, but taking even this into consideration, the fact could be demonstrated that the combined use of those durgs was more effective in improving the cerebral circulation and metabolism, comparing the cases, in which the blood pressure reduction occurred to the same extent. Namely, while in cases administered with Serpasil alone, a lowering of CVR and a slight increase of $\mathrm{CBF}$ and $\mathrm{CMRO}_{2}$ were observed, in the cases given with Serpasil in combination with Apresoline a more marked fall of GVR, a more marked increase of $\mathrm{CBF}$ and a moderate increase of $\mathrm{CMRO}_{2}$ were found, in particular, the striking augmentation of CBF was worthy of special mention here.

There are only a few reports on the effect of Serpasil on cerebral circulation and metabolism. Goto ${ }^{7)}$ studied the acute effect of lowering blood pressure by intravenous injection of Serpasil in 4 cases with essential hypertension and found that CBF was slightly increased in average value but the mean $\mathrm{CMRO}_{2}$ remained unchanged. Upon closer examination, his results show that both $\mathrm{CBF}$ and $\mathrm{CMRO}_{2}$ increase in the cases with mild retinal findings, but remain unchanged or decreased in the cases with advanced retinal changes-results in good agreement with the present investigation. Kleh and Fazekas $^{8)}$ reported that no significant change was found in the cerebral circulation and metabolism by oral administration of Serpasil, but their subjects were severe cases of hypertensive arteriosclerotic syndrome. No report on the effect of the combined use of Serpasil and Apresoline has been found, but on the use of Apresoline alone, a series of authors ${ }^{9 / 10111}$ have demonstrated marked increase in $\mathrm{CBF}$ after its administration, either by injection or per os; $\mathrm{McCall}^{10)}$ alone reporting on an increase of $\mathrm{CMRO}_{2}$ besides CBF.

The results of the present investigation with the combined use of Serpasil and Apresoline showing marked increase of CBF and increase of $\mathrm{CMRO}_{2}$ seem to suggest an additive action fo the two agents. At any rate, the improvement of CBF and CVR induced by these hypotensives 
indicates that they are valuable in preventing aggravation and occurence of cerebral complications in essential hypertension, and even the increase of $\mathrm{CMRO}_{2}$ found often indicates that those agents may be effective at least in some cases in improving the anomalies in cerebral metabolism.

Thus, those hypotensives should be noted as of therapeutic significance against reversible hypofunction of the cerebral cells.

Now, upon studying the effect of the hypotensives with consideration to the grade of the retinal findings in individual cases, an improvement of cerebral circulation and metabolism was found in most of the cases with mild retinal changes, but no improvement or even aggravation was noted in some cases with advanced retinal changes. Upon closer examination of the findings of 2 cases aggravated by administration of Serpasil alone, it must be noted that the cases were in II and III grade group of KeithWagener's retinal findings, respectively, and showed the high percentages of $-32.3 \%$ and $-33.1 \%$ in the drop of MABP, pressure drops much more marked than in any other subject who showed improvement.

From the above results obtained by the present investigation, the following conclusions may be drawn: In the cases with essential hypertension with mild retinal changes, prolonged oral administration of hypotensive agents may be expected to alleviate the changes in the cerebral circulation and metabolism, but in the cases with advanced retinal changes, sometimes no such improvement can be expected for and among the cases showing too conspicuous fall of the blood pressure after administration of the agents, even aggravation of the disturbance in the cerebral circulation may be caused thereby, sometimes leading to cerebral softning or other serious complications. For preventing such a mishap, much caution should be paid to avoid to lower the blood pressure excessively, taking the grade of retinal findings as index.

\section{Summary}

For studying the effects of lowered blood pressure induced by prolonged oral administration of hypotensive agents on the cerebral circulation and metabolism in essential hypertension, 7 cases with essential hypertension were administered with Serpasil alone and 4 cases with Serpasil in combination with Apresoline and the values concerning the cerebral circulation and metabolism before and after lowering blood pressure by those drugs were studied in comparison.

1. Following lowered blood pressure, cerebral vascular resistance (CVR) was found fallen in all the cases, cerebral blood flow (CBF) and cerebral oxygen consumption $\left(\mathrm{CMRO}_{2}\right)$ risen in most of the cases, showing a tendency to return to normal findings, but in a few cases of them CBF and $\mathrm{CMRO}_{2}$ were found unchanged or decreased. 
2. The combined use of Serpasil and Apresoline was found more effective in improving the cerebral circulation and metabolism than the single use of Serpasil.

3. In general, the improvement in the cerebral circulation and metabolism following lowered blood pressure was more marked in the cases with mild retinal findings and less in those with advanced retinal findings, and in 2 cases with marked reduction of the blood pressure was observed an aggravation of cerebral circulation and metabolism and one of them was followed by complication with cerebral softning.

4. Details on one of the cases that showed improvement and one that showed deterioration after lowering blood pressure were given.

5. It was infered that for preventing serious complications by use of hypotensive agents much caution should be paid to avoid to lower the blood pressure excessively, taking the grade of retinal findings as index.

The expense of this study was in part defrayed by a Grant in Aid ofr Medical Research, Welfare Ministry. The author wishes to express his thanks to Dr. S. Sato, chief doctor of our Medical Clinic for co-operation in carrying out this investigation.

\section{References}

1) Tateyama, Tohoku J. Exp. Med., 1959, 70, 115.

2) Kety et al., J. Clin. Invest., 1948, 27, 511.

3) Hafkenshiel et al., J. Clin. Invest., 1954, 33, 63.

4) Fazekas et al., Amer. J. Med., 1955, 18, 477.

5) Shenkin et al., J. Clin. Invest., 1953, 32, 459.

6) Tazaki, Naikagakkai Zasshi (Jap.), 1956, 45, 731.

7) Goto, et al., Shinryo (Jap.), 1955, 8, 611.

8) Kleh and Fazekas, Amer. J. Med. Sci., 1954, 228, 560.

9) Kleh and Fazekas, ibid., 1954, 227, 57.

10) McCall, Amer. J. Obst. Gynecol., 1953, 66, 1015.

11) Tazaki, Keio Igaku (Jap.), 1954, 31, 252. 